\title{
Dijagnostika i razvoj funkcionalnih sposobnosti stonotenisera
}

Branko Đukić

Pokrajinski zavod za sport i medicinu sporta, Novi Sad

\begin{abstract}
Table tennis is acyclic, polistructural sports activity which requires a high degree of physical, psychological, technical and tactical preparedness of the athlete. In the function of development and maintenance of functional ability high level, variety of methods impose, apply different training means, methods and loads. In this paper are presented laboratory and field testing results of aerobic functional capabilities of best ping pong players of Serbia and Serbian youth team before the European Championships in Bratislava in 2015, as well as exercises that can be applied in the training process of functional abilities development. Dosage, intensity and exercise selection should depend on the level of athletes physical fitness, and the level of adoption and trained kicks, athletes age, training periodization and etc.
\end{abstract}

Keywords: table tennis, functional capabilities, diagnostics, exercises.
Sažetak: Stoni tenis je polistrukturalna aciklicna sportska aktivnost koja od sportista zahteva visok stepen fizičke, psihološke, tehničke i taktičke pripremljenosti. U funkciji razvoja i održavanja visokog nivoa funkcionalnih sposobnosti nameću se različite metode rada, primenjuju različiti trenažni operatori, odnosno sredstva, metode i opterećenja. U radu su predstavljeni rezultati laboratorijskog i terenskog testiranja aerobnih funkcionalnih sposobnosti najboljih srpskih stonoteniserki i mlade selekcije Srbije pred EP u Bratislavi 2015. godine, kao i vežbe koje se mogu primenjivati u trenažnom procesu prilikom razvoja funkcionalnih sposobnosti sportista. Doziranje, intenzitet i izbor vežbi treba da zavisi od nivoa fizičke pripremljenosti sportiste, stepena usvojenosti i uvežbanosti udaraca, uzrasta sportista, periodizacije treninga $\mathrm{i} \mathrm{dr}$.

Ključne reči: stoni tenis, funkcionalne sposobnosti, dijagnostika, vežbe

Rad je primljen 10.05.2016.

Odobren 12.05.2016.

Kontakt podaci:

Branko Đukić

Pokrajinski zavod za sport i medicinu sporta

Novi Sad, Masarikova 25/II

Tel: +38121572224

E-mail: branko.djukic@pzsport.rs 


\section{Uvod}

Pored razvoja motoričkih za stoni tenis veoma je važno i unapređenje funkcionalnih sposobnosti. U napornim i dugim sezonama, a još više na dugotrajnim turnirima, dobra fizička priprema igrača predstavlja ključ uspeha u stonoteniskoj igri. Visok nivo fizičke pripreme, podrazumeva visoko razvijene motoričke i funkcionalne sposobnosti. U savremenom trenažnom procesu bilo koje sportske grane, za usvajanje i uvežbavanje tehničko-taktičkih elemente tog sporta, potreban je odgovarajući nivo fizičke pripremljenosti igrača. U razvoju fizičkih sposobnosti igrača ne treba zanemariti one sposobnosti koje su od velikog značaja za tu sportsku granu. Za postizanje vrhunskih rezultata $\mathrm{u}$ stonom tenisu neophodno je da se trenažni proces oslanja na rezultate naučnih istraživanja.

Stoni tenis ima reputaciju najbrže igre sa loptom. Brzina loptice u stonom tenisu zavisi od vrste udarca i energije uložene u izvođenje udarca. Brzine se kreću od $20 \mathrm{~km} / \mathrm{h}$ do $160 \mathrm{~km} / \mathrm{h}$. Brzina reketa sa lopticom, naravno, puno je manja od brzine leta loptice i dostiže do $50 \mathrm{~km} / \mathrm{h}$. Karakteristike stonog tenisa govore da je ova sportska igra jedna od zahtevnijih igara kada se uzme u obzir da se loptica obrne oko svoje ose 170 puta u sekundi (Kondrič, Hudetz, FurjanMandić, 2010).

Funkcionalne sposobnosti sportista su kardiorespiratorne i aerobne sposobnosti odgovorne za transport kiseonika, kao i metaboličke sposobnosti odgovorne kako za aerobne, tako $\mathrm{i}$ za anaerobne sposobnosti. Kardiovaskularni sistem je zadužen za veliki broj funkcija u organizmu. Značajna je uloga ovog sistema u isporuci kiseonika i hranljivih sastojaka, eliminaciji ugljen-dioksida i metaboličkih nusproizvoda iz mišića i ostalih tkiva, transportu složenih materija do jetre i ostalih organa, pomoći $\mathrm{u}$ regulaciji telesne temperature $\mathrm{i}$ isporuka hormona do ciljnih tkiva u organizmu. Stoga se poboljšanjem kardiovaskularnog sistema povećava celokupna fiziološka funkcija sportiste (Drid,2012).

Funkcionalna dijagnostika u sportu obuhvata široko područje od registrovanja opštih funkcionalnih sposobnosti u rutinskoj laboratorijskoj sportsko-medicinskoj praksi, preko dubljeg uvida $u$ pojedine fiziološke $i$ biohemijskeprocese do istraživanja i merenja na sportskim terenima, u situacionim uslovima (Sudarov, Fratrić, 2010).

Kardiorespiratorna izdržljivosti u stonom tenisu je od velikog značaja, imajući u vidu trajanje mečeva, broj mečeva u toku dana na turnirskim takmičenjima od nekoliko dana, zgusnutom kalendaru takmičenja. Sve ove karakteristike stonog tenisa zahtevaju viši nivo aerobnog kapaciteta igrača. Testiranje na početku, $\mathrm{u}$ toku i na kraju sezone, bi pomogla stonoteniskim stručnjacima u programiranju trenažnog procesa.

Za postizanje vrhunskih sportskih rezultata sportisti danas moraju da budu dobro fizički pripremljeni. Odgovarajuća adaptacija organizma sportiste u procesu sportskog treninga ostvariće se jedino, ako odgovarajuće antropološke, motoričke i funkcionalne karakteristike pojedinog sportiste prati i odgovarajući trenažni plan i program. $\mathrm{Na}$ postizanje optimalnog stanja treniranosti sve više utiču dostignuća nauke iz oblasti sporta i dijagnostika treniranosti sportista. Vrhunska sportska dostignuća rezultat su sinergijskog delovanja niza međuzavisnih faktora (nasleđe, antropološka obeležja i sposobnosti, sportski trening, itd). Kako bi trener s timom stručnjaka došao do potrebnih informacija, treba pravovremeno sprovesti dijagnostiku stanja treniranosti sportista (Vučetić, Šentija, 2005).

Dijagnostika u sportu podrazumeva određivanje sposobnosti i osobina sportiste koje su bitne za uspeh u sportu. Kako bi se na pravi način pristupilo razvoju funkcionalnih sposobnosti potrebno je sprovesti inicijalno, tranzitno $\mathrm{i}$ finalno merenje tokom trenažnog procesa sa ciljem da se utvrdi efikasnost aerobnih $i$ anaerobnih funcionalnih mehanizama i efekti programiranog treninga.

\section{Dijagnostika funkcionalnih sposobnosti}

Osnovni cilj uspešnog sprovođenja transformacionog procesa sportskog treninga je primena dijagnostifikovanja inicijalnog stanja sportiste, odnosno, trenažnog stanja u kome se sportista nalazi na početku trenažnih priprema (Malacko, Rađo, 2004). Kako bi se na pravi način pristupilo razvoju funkcionalnih sposobnosti, potrebno je sprovesti inicijalno, tranzitno i finalno merenje tokom trenažnog procesa sa ciljem da se utvrdi efikasnost aerobnih i anaerobnih funkcionalnih mehanizama i efekti programiranog treninga.

Prilikom procene određenih sposobnosti i karakteristika igrača u određenoj sportskoj grani, potrebno je uspešno koristiti merne instrumente, adekvatne testove, kao i na pravi način obraditi i analizirati rezultate merenja. $\mathrm{Na}$ osnovu dostupnih radova koji se bave dijagnostikom energetskih kapaciteta, odnosno, aerobnih $\mathrm{i}$ anaerobnih 
sposobnosti sportista uglavnom se koriste standardizovani protokoli testova.

Dijagnostika predstavlja niz postupaka kojima se utvrđuju individualne karakteristike pojedinca, a koje se sprovode različitim testiranjima njegovih ključnih sposobnosti i osobina za konkretnu sportsku disciplinu. Cilj dijagnostike je da proceni morfološke karakteristike ispitanika, stanje motoričkih, funkcionalnih i psihičkih sposobnosti i karakteristika, kao i nivo specifičnih svojstava pojedinca. Dijagnostikovati kolike su funkcionalne i motoričke sposobnosti važno je i zbog mogućnosti utvrđivanja trenutnog stanja vrhunskog sportiste i provere odstupanja odnormative, koji je zadat jednačinom specifikacije pojedinog sporta, kao i koliko to trenutno stanje odstupa od postavljenog cilja. Za postizanje vrhuskih sportskih rezultata sportisti danas moraju da budu izuzetno dobro fizički pripremljeni. U svim sportovima dijagnostika se sprovodi u cilju identifikacije talenata i njihove selekcije, definisanja aktuelnog (trenutnog) stanja sposobnosti sportista, te praćenja efekata samog treninga (program, obimi, intenzitet, izbor vežbi i procesa) (Drid, 2012).

Dijagnostikom funkcionalnih sposobnosti, $\mathrm{u}$ uslovima precizno kontrolisanih opterećenja, dobijaju se informacije o trenutnom funkcionalnom stanju kardiovaskularnog, respiratornog i mišićnog sistema za obavljanje osnovnog zajedničkog zadatka - razmenu gasova.Važan faktor u fizičkoj pripremi stonotenisera je aerobna komponenta. Zadovoljavajući nivo efikasnosti aerobnog kapaciteta smanjuje mogućnost stvaranja mlečne kiseline, odnosno, ubrzava njenu razgradnju što posledično utiče na smanjeno vreme odmora i efikasniji učinak tokom treninga ili takmičarske igre (Kondrič, Furjan-Mandić, 2002).

Testovi kojima se dijagnostikuju energetski kapaciteti se mogu podeliti na: laboratorijske i terenske testove, specifične i nespecifične testove, testove sa fiksnim i progresivnim opterećenjem, na kontinuirane i diskontinuirane testove. Sam napredak sportsko dijagnostičke tehnologije omogućava lakše, jeftinije i preciznije laboratorijsko i terensko merenje kapaciteta odgovornih za energetsko snabdevanje organizma za vreme sportske aktivnosti. Sve više su dostupniji pulsmetri koji se koriste u trenažnom procesu i pomažu sportistima $\mathrm{i}$ trenerima $\mathrm{u}$ kreiranja plana i programa rada, te odabira trenažnim operatora.

Postoji dosta radova koji su se bavili kontrolom funkcionalnih sposobnosti stonototenisera, značajem utvrđivanja stanja kako aerobnog, tako i anaerobnih kapaciteta stonotenisera.

Autor (Suchomel, 2010) se u radu bavio utvrđivanjem nivoa intenziteta treninga za igrače koji nastupaju u različitim nivoima takmičenja u stonom tenisu. Cilj istraživanja je bio poređenje fizičke pripremljenosti stonotenisera i intenziteta opterećenja tokom pojedinačnih mečeva sa posebnim osvrtom na različit nivo kvaliteta igrača. U istraživanju su učestvovala 33 igrača muškog pola, podeljena u 3 uzorka ispitivanja: rekreativni, regionalni i ligaški (profesionalni) nivo. Svi učesnici su bili podvrgnuti testiranju progresivnim kontinuiranim protokolom testa na pokretnoj traci za procenu maksimalne potrošnje kiseonika (VO2max). Srčana frekvenca je praćena pulsmetrom (Polar RS800), tokom tri stonoteniska meča odigrana do 11 poena sa protivnicima sličnog kvaliteta igre. Otkucaji srca beleženi su u intervalima od jedne sekunde. Mečevi su odigravanina tri dobijena seta do 11 poena, između protivnika istog nivoa. Rezultati ovog istaživanja su pokazali značajne razlike $u$ aerobnom kapacitetu igrača (VO2max) i opterećenju srca između igrača rekreativnog, regionalnog i ligaškog nivoa.Najbolji rezultati zabeleženi su kod igrača ligaškog nivoa. Autor piše u radu da su vrednosti VO2max, kao osnovnog pokazatelja aerobnog kapaciteta, za 40$60 \%$ veće kod mušaraca nego kod žena, da najveće vrednosti postižu sportisti koji se bave biciklizmom ili skijanjem sa 75 , čak $85 \mathrm{mlO} 2 / \mathrm{kg} / \mathrm{min}$.

$\mathrm{U}$ tabeli 1 se mogu videti postignute vrednosti prosečne maksimalne potrošnje kiseonika $\mathrm{VO}_{2 \max }$, srednje vrednosti srčane frekvence u miru i maksimalne vrednosti srčane

Tabela 1. Rezultati testiranja funkcionalnih sposobnosti sportista različitog nivoa

\begin{tabular}{|c|c|c|c|}
\hline Nivo sportista & Rekreativci & Regionalna liga & Profesionalci \\
\hline Broj testiranih sportista & 11 & 11 & 11 \\
\hline VO2max (ml/kg/min) & $\mathbf{4 2 . 7} \pm \mathbf{4 . 2}$ & $\mathbf{4 8 . 6} \pm \mathbf{4 . 8}$ & $\mathbf{6 2 . 1} \pm \mathbf{5 . 1}$ \\
\hline HR u miru & $67 \pm 5$ & $62 \pm 4$ & $54 \pm 4$ \\
\hline Hr max & $189 \pm 5$ & $191 \pm 6$ & $196 \pm 5$ \\
\hline
\end{tabular}


frekvence zabeležene u toku odigravanja meča. Dobijeni rezultati testiranja nam pokazuju da su najbolje vrednosti zabeležene kod profesionalnih sportista, što predstavlja logičan zaključak, uzimajući u obzir intenzitet i obim trenažnog procesa kojem su podvrgnuti.

Pregledom različitih radova stranih i domaćih autora, koji se bave fizioloških aspektima u stonom tenisu, zaključujemo da se za procenu anaerobnih funkcionalnih sposobnosti najčešće koriste uobičajeni standardizovani Wingate test.

$\mathrm{Da}$ bi merenje i evaluacija kako funkcionalnih sposobnosti, tako i motoričkih, konativnih, kognitivnih sposobnosti, morfoloških karakteristika, potrebno je primenjivati odabrane merne instrumente i testove, koji pre svega treba da budu validni, pouzdani i objektivni. Pored ovih kriterijuma, neophodno je da proces merenja i analize rezultata sprovode osobe koje su stručno obučene za ovaj posao.

\section{Laboratorijsko testiranje funkcionalnih sposobnosti stonotenisera}

Danas se pretežno koriste kontinuirani testovi opterećenja na biciklergometru i pokretnoj traci, gde se porast opterećenja postiže ili povećanjem brzine trake (Taylorov test mod.) ili povećanjem nagiba trake (Balke, UCLA test) ili se pak i brzina i nagib progresivno povećavaju (Brus).

Spiroergometrijskisistem (CPET) i pripadajući programski paket Quark (COSMED,
Italy), omogućava kontinuirano on-line, breathbybreath praćenje potrošnje kiseonika (VO2, STPD), izdahnutog ugljendioksida (VCO2, STPD), frekvencije srčanog ritma (FS), minutnog volumena disanja (VE, BTPS), respiratornog koeficijenta (RQ), koncentracije gasova $u$ izdahnutom zraku (PETCO2, PETO2), disajnog volumena $(\mathrm{Vt})$, frekvencije disanja $(\mathrm{BF})$, pulsa kiseonika (PO2), te disajnog ekvivalenata za kiseonik (VE/VO2) i ugljen dioksid (VE/VCO2). Uz ove parametre, istim testom mogu se pratiti i vrednosti frekvencije srca (monitorom Cosmed), subjektivne percepcije opterećenja (upotrebom Borgove lestvice), te koncentracije laktata u krvi na kraju progresivnog testa. Svaki od primenjenih protokola opterećenja na pokretnoj traci započinje mirovanjem na traci u prvom minutu uz praćenje svih ventilacionih i metaboličkih parametara. Protokol se nastavlja hodanjem pri brzini od 3 $\mathrm{km} / \mathrm{h}$. Trajanje pojedinog stepena opterećenja i povećanje brzine trake zavisi od protokola. Ispitanik počinje da trči pri brzini od $7 \mathrm{~km} / \mathrm{h}$. Nagib trake je konstantan i iznosi 1,5\%.

$\mathrm{U}$ tabelama2,3,4 koje se nalaze ispod su prikazani parametri dobijeni testiranjem aerobnih sposobnosti stonoteniserki Stonoteniskog kluba "Novi Sad", šampionki Super lige Srbije u sezoni 2014/15, direktnim merenjem potrošnje kiseonika progresivnim kontinuiranim testom na pokretnoj traci (sistem Quark CPET, COSMED), na osnovu kojih se procenjuju maksimalna potrošnja kiseonika i ventilacijski anaerobni prag, osnovne mere aerobne izdržljivosti.

Tabela 2. Spiroergometrija (step: $0.5 \mathrm{~km} \cdot \mathrm{h}^{-1} / 30 \mathrm{sek}$, inkl.: 1.5\%)

\begin{tabular}{|l|l|c|c|c|c|c|}
\hline Br. & Naziv & Mer. jedin & Igračica 1 & Igračica 2 & Igračica 3 & Igračica 4 \\
\hline 1. & Max. potrošnja kiseonika & $l O_{2} /$ min & 2.30 & 2.31 & 3.58 & 2.88 \\
\hline 2. & Rel. max. potrošnja kiseonika & $\mathbf{m l O}_{2} / \mathbf{k g} /$ min & $\mathbf{4 5 . 6 6}$ & $\mathbf{3 7 . 4 9}$ & $\mathbf{4 1 . 9 3}$ & $\mathbf{4 4 . 0 8}$ \\
\hline 3. & Max. frekvenca srca & otk/min & 183 & 194 & 186 & 190 \\
\hline 4. & Max. kiseonički puls & $\mathrm{mlO}$ & 12.7 & 12.0 & 20.5 & 15.2 \\
\hline 5. & Max. min. ventilacija & $\mathrm{l} / \mathrm{min}$ & 72.7 & 86.6 & 105.1 & 89.2 \\
\hline 6. & Max. disajni volumen & $l$ & 1.21 & 1.51 & 2.02 & 2.25 \\
\hline 7. & Max. frekvenca disanja & $\mathrm{l} / \mathrm{min}$ & 65.9 & 61.7 & 54.8 & 43.2 \\
\hline 8. & Brzina trăanja pri $\boldsymbol{V O}_{2}$ max & $\mathrm{Km} / \mathrm{h}$ & 13.0 & 12.5 & 12.5 & 12.5 \\
\hline 9. & Max. brzina trčanja & $\mathrm{Km} / \mathrm{h}$ & 13.0 & 13.0 & 13.0 & 13.0 \\
\hline
\end{tabular}

Tabela 3. Ventilacijski anaerobni prag

\begin{tabular}{|c|c|c|c|c|c|c|}
\hline$B r$ & Naziv & Mer. jedinica & Igračica 1 & Igračica 2 & Igračica 3 & Igračica 4 \\
\hline 1. & Intenzitet opterećenja & $\mathrm{km} / \mathrm{h}$ & 10.5 & 9.0 & 9.5 & 10.5 \\
\hline 2. & Tempo trčanja & $\mathrm{min} / \mathrm{km}$ & $5: 42$ & $6: 40$ & $6: 27$ & $5: 42$ \\
\hline 3. & $\begin{array}{l}\text { Relativna potrošnja } \\
\text { kiseonika }\end{array}$ & $\mathrm{mlO}_{2} / \mathrm{kg} / \mathrm{min}$ & 37.15 & 30.20 & 34.47 & 38.64 \\
\hline 4. & Aps.potrošnja kis. & $l \mathrm{O}_{2} / / \min$ & 1.87 & 1.86. & 2.94 & 2.53 \\
\hline 5. & $\%$ od VO2max & $\%$ & 81 & 80 & 82 & 88 \\
\hline 6. & Frekvenca srca & otk/min & 167 & 176 & 165 & 175 \\
\hline 7. & $\%$ od FSmax & otk/min & 91 & 92 & 89 & 92 \\
\hline
\end{tabular}


Tabela 4. Procena anaerobnog kapaciteta

\begin{tabular}{|l|l|c|c|c|c|c|}
\hline Br. & Naziv & Mer. jedin & Igračica 1 & Igračica 2 & Igračica 3 & Igračica 4 \\
\hline 1. & $\begin{array}{l}\text { Izdrăaj u anaerobnoj zonit } \boldsymbol{a n}_{n}=v_{\max }- \\
v_{\text {anp }}\end{array}$ & $\min$ & $2^{\prime} 50^{\prime \prime}$ & $4^{\prime} 07^{\prime \prime}$ & $3^{\prime} 27^{\prime \prime}$ & $2^{\prime} 38^{\prime \prime}$ \\
\hline
\end{tabular}

\section{Primer ocene aerobne izdržljivosti za igračicu 4}

Aerobni kapacitet $(\mathrm{VO} 2 \mathrm{max}=44.08 \mathrm{ml} / \mathrm{kg}$, postignut pri brzini trčanja od $12.5 \mathrm{~km} / \mathrm{h}$ ), utvrđen direktnim merenjem potrošnje kiseonika progresivnim kontinuiranim testom na pokretnoj traci (sistem Quark CPET, COSMED). Rezultat je $\mathrm{u}$ rangu dobrih stonoteniserki.

Anaerobni ventilacijski prag postignut je pri opterećenju od $10.5 \mathrm{~km} / \mathrm{h}$ i potrošnji kiseonika od $38.64 \mathrm{ml} / \mathrm{kg}$ ( $88 \%$ VO2max), te frekvenciji srca od 175/min (odgovara tempu od oko 5:42 $\mathrm{min} / \mathrm{km}$ ). Nešto duži raspon u testu, od anaerobnog praga do maksimalnog opterećenja, ukazuje na dobar anaerobni kapacitet/specifičnu izdržljivost. svaki minut za $0,5 \mathrm{~km} / \mathrm{h}$. Svaki minut se interpretira kao jedan nivo, a unutar jednog nivoa ima od 8-12 deonica.

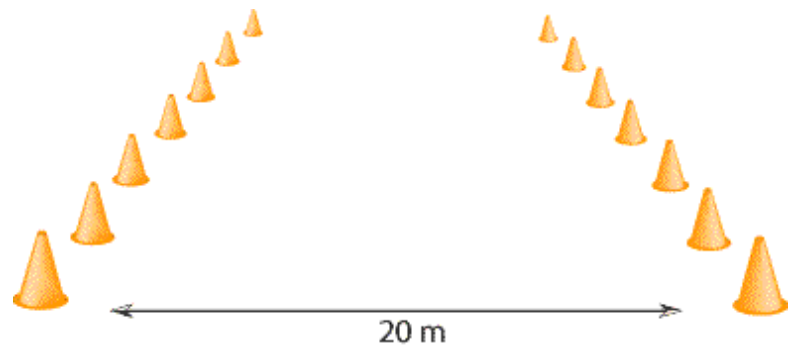

Ovaj standardizovani test uz ostale testove agilnosti, ekslozivne snage, fleksibilnosti sproveli su stručnjaci iz Zavoda za sport i medicinu sporta Republike Srbije na pripremama kadetske i

Tabela 5. Prema spiroergometrijskim parametrima su određene pulsne zone za sve testirane igračice:

\begin{tabular}{|l|c|c|c|c|}
\hline \multirow{2}{*}{ Zoneintenziteta } & \multicolumn{4}{c|}{ Frekvencija srca } \\
\cline { 2 - 5 } & Igračica 1 & Igračica 2 & Igračica 3 & Igračica 4 \\
\hline Regeneracijska zona: & $<117$ & $<123$ & $<115$ & $<122$ \\
\hline Zona ekstenzivnog aerobnog treninga: & $117-150$ & $123-158$ & $115-148$ & $122-157$ \\
\hline Zona intenzivnog aer. treninga - zona praga: & $150-167$ & $158-176$ & $148-165$ & $157-175$ \\
\hline Zona maksimalne potrošnje kiseonika & $>167$ & $>176$ & $>165$ & $>175$ \\
\hline
\end{tabular}

U tabelama koje se nalaze iznad se vide parametri koji opisuju stanje treniranosti stonoteniserki, odnosno razvijenosti njegovog aerobnog kapaciteta na osnovu kojih sportski stručnjaci, odnosno, njihovi treneri mogu da programiraju trenažni proces, tj. opterećenja i doziranje samih stonoteniskih vežbi.

\section{Terensko testiranje funkcionalnih sposobnosti
stonotenisera}

Jedan od češće primenjivanih terenskih testova za procenu aerobnih sposobnosti je Beep test. Beep test je u sportskoj praksi vrlo popularan polu-labaratorijski test progresivnog tipa. Izvodi se u zatvorenom prostoru, ide do maksimalnog iscrpljenja, a jedna od važnijih činjenica je da iskustvo ispitanika praktično nema uticaja. Test se odvija na markiranom prostoru od 20 metara pri čemu se trčanje odvija od jedne markacije do druge, a prati se brzina koju daje zvučni signal (beep) sa nekog plejera.Pojedini "beep" ubrzava juniorske stonoteniske selekcije Srbije u Subotici u julu 2015.godine.

Za procenu VO2max primenom Beep testa koristi se sledeći algoritam (prema Legel i Gadoury, 1989):

$\operatorname{VO2max}(\mathrm{ml} / \mathrm{kg} / \mathrm{min})=18.043461+(0.3689295$ $x$ TS) + (-0.000349 x TS x TS)

gde je TS ukupan broj intervala (Tabela 6).

U tabeli 7. su prikazane vrednosti maksimalne potrošnje kiseonika kadetske i juniorske muške i ženske selekcije Srbije u stonom tenisu. Rezultati su dobijeni indirektnim načinom uz primenu formule VO2max $(\mathrm{ml} / \mathrm{kg} / \mathrm{min})=18.043461+(0.3689295 \times \mathrm{TS})+(-$ $0.000349 \times \mathrm{TS} \times \mathrm{TS})$. Bolji rezultati juniora $\mathrm{i}$ juniorki od kadeta i kadetkinja su logični i posledica su dužeg i intenzivnijeg trenažnog procesa. 
Tabela 6. Broj predjenih intervala nakon svakog nivoa u Beep testu (Sudarov, 2007.)

\begin{tabular}{|c|c|c|c|c|c|c|c|c|c|c|c|}
\hline Nivo & $\mathbf{1}$ & $\mathbf{2}$ & $\mathbf{3}$ & $\mathbf{4}$ & $\mathbf{5}$ & $\mathbf{6}$ & $\mathbf{7}$ & $\mathbf{8}$ & $\mathbf{9}$ & $\mathbf{1 0}$ & $\mathbf{1 1}$ \\
\hline Interval & 8 & 16 & 24 & 33 & 42 & 52 & 62 & 73 & 84 & 95 & 107 \\
\hline Nivo & 12 & 13 & 14 & 15 & 16 & 17 & 18 & 19 & 20 & 21 & 22 \\
\hline Interval & 119 & 132 & 145 & 158 & 172 & 186 & 201 & 216 & 232 & 248 & 264 \\
\hline
\end{tabular}

Tabela 7. Vrednosti VO2max-Beep test

\begin{tabular}{|l|c|c|c|c|}
\hline \multicolumn{5}{|c|}{ Beep test-mlada stonoteniska reprezentacija Srbije } \\
\hline kategorija & Vrednosti VO2max $(\mathrm{mlO} / \mathrm{kg} / \mathrm{min})$ & \\
\hline juniori & $\mathbf{5 4 , 6 9 ( 1 7 )}$ & $51,75(16)$ & $53,23(18)$ & $56,71(16)$ \\
\hline kadeti & $43,12(14)$ & $46,26(15)$ & $46,26(15)$ & $46,26(15)$ \\
\hline juniorke & $45,32(18)$ & $42,48(18)$ & $44,7(16)$ & $46,57(16)$ \\
\hline kadetkinje & $42,48(15)$ & $44,07(12)$ & $42,8(12)$ & $43,26(12)$ \\
\hline \multicolumn{4}{|c|}{ Brojevi u zagradama označavaju godine starosti sportista } \\
\hline
\end{tabular}

\section{Razvoj funkcionalnih sposobnosti stonotenisera}

Pored uobičajenih metoda koji se koriste i u drugim sportskim disciplinama, postoje različiti metodi za razvoj aerobnih i anaerobnih specifičnih sposobnosti sportista u stonoteniskom treningu.Najbolji način razvoja funkcionalnih sposobnosti su situacijske vežbe slične samoj igri, u kojima se primenjuju kretanja i pokreti udaraca, kao i u meču. Pored vežbi za stolom koje su osnova treninga $\mathrm{u}$ stonom tenisu, najčešće su korišćene imitacijske i "many balls" vežbe.

Cilj dijagnostike funkcionalnih sposobnosti stonotenisera je određivanje trenažnih pulsnih zona opterećenja i njihovo korišćenje u daljem radu. Zona opterećenja u kojoj se igrač nalazi i dužina trajanja opterećenja govori da li razvijamo aerobnu ili anaerobnu izdržljivost. Ukoliko se igrači nalaze u zoni ekstenzivnog aerobnog treninga razvijamo aerobne sposobnosti, a u zoni intenzivnog aerobnog treninga i zoni maksimalne potrošnje kiseonika razvijamo anaerobne sposobnosti.

Primena imitacijskih vežbi u specifičnosituacionoj kondicionoj pripremi stonotenisera

Imitacijske vežbe u funkciji razvoja funkcionalnih sposobnosti stonotenisera se mogu izvoditi bez reketa, sa težim reketom i sa tegovima ukoliko se želi poboljšati eksplozivna snaga i izdržljivost igrača. Ove vežbe se koriste tek kada su udarci igrača automatizovani. U zavisnosti od nivoa treniranosti igrača, vežbe se mogu izvoditi u trajanju od 20-30 sekundi u 5-10 serija sa ciljem poboljšanja aerobno-anaerobnih sposobnosti. Ako ovim vežbama želimo uticati na poboljšanje eksplozivne snage, treba koristiti teži reket i tegove od $0,5 \mathrm{~kg}$ na nogama. Vežbe treba prekinuti kada je očigledno narušena forma pokreta, što predstavlja znak zamora igrača.

Tabela 8. Kompleksimitacijskih vežbi sa ciljem razvoja funkcionalnih sposobnosti

\begin{tabular}{|c|c|c|}
\hline $\begin{array}{l}\text { Broj } \\
\text { vežbi }\end{array}$ & Opis imitacijske vežbe & Primena \\
\hline 1. & $\begin{array}{l}\text { forhend spin iz forhend ugla stola, sa sredine stola i iz bekhend } \\
\text { ugla stola-tri udarca }\end{array}$ & \multirow{6}{*}{$\begin{array}{l}\text { U treningu predstavljeni kompleks } \\
\text { vežbi treba izvoditi intenzitetom } \\
\text { oko } 70-80 \% \text { od maksimalne } \\
\text { srčane frekvence. Vežba se radi } 20 \\
\text { sekundi sa pauzom između vežbi } \\
\text { od } 10 \text { sekudi. } \\
\text { Prilikom izvođenja vežbi igrači } \\
\text { treba da pokrete udaraca izvode } \\
\text { identično, kao u igri sa reketom i } \\
\text { lopticom. } \\
\text { Igrači rade tri serije, a pauza } \\
\text { između serija je } 3 \text { minuta. }\end{array}$} \\
\hline 2. & $\begin{array}{l}\text { dva fhspina iz fh ugla stola, dva fhspinasa sredine stola i dva } \\
\text { fhspina iz bhugla stola-šest udarca }\end{array}$ & \\
\hline 3. & $\begin{array}{l}\text { fh spin iz fh ugla stola, bh spin i bh ugla stola, iskakanjem, fh } \\
\text { spin iz bh ugla i fh spin iz fh ugla-četiri udarca }\end{array}$ & \\
\hline 4. & $\begin{array}{l}\text { kretanjem napred-nazad igrač izvodi fh flip (aktivni udarac na } \\
\text { kratku loptu-spin sa stola) i fh spin sa sredine stola-dva udarca }\end{array}$ & \\
\hline 5. & $\begin{array}{l}\text { kretanjem napred-nazad igrač izvodibh flip, fh spin iz fh ugla } \\
\text { stola i fh udarac iz bh dela stola-tri udarca }\end{array}$ & \\
\hline 6. & $\begin{array}{l}\text { izvođenje fh } \mathrm{i} \text { bh udaraca iz svih polja stola simulacijom } \\
\text { slobodne igre sa čestim kretanjima napred-nazad. }\end{array}$ & \\
\hline
\end{tabular}


Primena "Many balls" treninga u specifično-situacionoj kondicionoj pripremi stonotenisera

"Many balls" trening je oblik rada koji treneri često upotrebljavaju u samom treningu. Izvodi se po principu intervalnog treninga i ima brojne prednosti u odnosu na ostale metode treniranja. Intervalni aerobni trening "Many balls" sastoji se od ponavljanja intervala kratkog ili srednjeg trajanja visokog intenziteta, koji je isprekidan aktivnim ili pasivnim pauzama. trenažnog procesa treba biti obazriv u primeni "Many balls" metode intervalnog treninga, kako sportisti ne bi došli u fazu pretreniranosti. Preporuka autora je da se u cilju razvoja funkcionalnih i motoričkih sposobnosti ovaj trening primenjuje 2-3 puta nedeljno i najviše dva dana pred samo takmičenje, kako bi sportisti imali dovoljmo vremena za oporavak.

Tabela 9. Primer "Many balls" metoda intervalnog treninga

\begin{tabular}{|c|c|c|}
\hline $\begin{array}{l}\text { Broj } \\
\text { vežbi }\end{array}$ & Opis Many balls vežbe & Primena \\
\hline 1. & $\begin{array}{l}\text { forhend spin iz forhend ugla stola, sa sredine stola i iz } \\
\text { bekhend ugla stola-tri udarca na "čistu" lopticu }\end{array}$ & \multirow{6}{*}{$\begin{array}{l}\text { U treningu predstavljeni kompleks vežbi } \\
\text { treba izvoditi intenzitetom oko } 70-80 \% \\
\text { od maksimalne srčane frekvence. Vežba } \\
\text { se radi } 20 \text { sekundi sa pauzom između } \\
\text { vežbi od } 10 \text { sekundi. } \\
\text { Prilikom izvođenja vežbi igrači treba da } \\
\text { pokrete udaraca izvode tehnički } \\
\text { ispravno. } \\
\text { Igrači rade tri serije, a pauza između } \\
\text { serija je } 3 \text { minuta. }\end{array}$} \\
\hline 2. & $\begin{array}{l}\text { fhspin iz fh ugla stola,fhspin sa sredine stola i bh spin iz } \\
\text { bhugla stola-na rezanu lopticu }\end{array}$ & \\
\hline 3. & $\begin{array}{l}\text { fh spin iz fh ugla stola, bh spin i bh ugla stola, iskakanjem, } \\
\text { fh spin iz bh ugla i fh spin iz fh ugla-četiri udarca }\end{array}$ & \\
\hline 4. & $\begin{array}{l}\text { kretanjem napred-nazad igrač izvodi fh flip, fh spin iz bh } \\
\text { ugla stola i fh top spin iz dubokog fh ugla stola }\end{array}$ & \\
\hline 5. & $\begin{array}{l}\text { kretanjem napred-nazad igrač izvodibh flip, fh spin iz fh } \\
\text { ugla stola, fh udarac iz bh dela stola i dva fh top spina bez } \\
\text { sablona. }\end{array}$ & \\
\hline 6. & $\begin{array}{l}\text { izvođenje fh } \mathrm{i} \text { bh udaraca iz svih delova stola čestim } \\
\text { kretanjima napred- nazad. }\end{array}$ & \\
\hline
\end{tabular}

Trener je u ulozi ubacivača loptica koje šalje ka igraču jednu za drugom određenim tempom i ritmom sa i bez rotacije loptice u određeni deo stola i u određenim intervalima rada i odmora. Prilikom ubacivanja loptica trener primenjuje udarce koji treba da budu što sličniji udarcima iz same igre $u$ pogledu visine, rotacije $i$ brzine loptice. Brzina i tempo ubacivanja loptica u igru treba da bude takva da su igrači tokom rada sposobni da izvode tehnički ispravno pokrete udaraca. Osim uticaja na razvoj funkcionalnih i specifičnih motoričkih sposobnosti značajnu ulogu ima u učenju i usavršavanju tehnike stonoteniskih udaraca, ispravljanju tehničkih grešaka, sticanju sigurnosti u udarcima i u taktičkom treningu.

Metoda se izvodi tako što trener ubacuje loptice $u$ igru, kontrolišući na štoperici vreme (radi promene vežbe). Najbolje je kad intervalni trening u grupi rade dva do tri igrača.

Dok jedan igrač radi, drugi koji je završio rad, lagano se isteže i odmara. Za ovu vrstu intervalnog treninga potrebno je obezbediti veliki broj loptica - oko 200-300 komada.

Predstavljeni trening (slika 1) moguće je dodatno otežati upotrebom gumenih traka, nožnih tegova i prsluka i na taj način akcenat staviti na razvoj snažne izdržljivosti. U programiranju

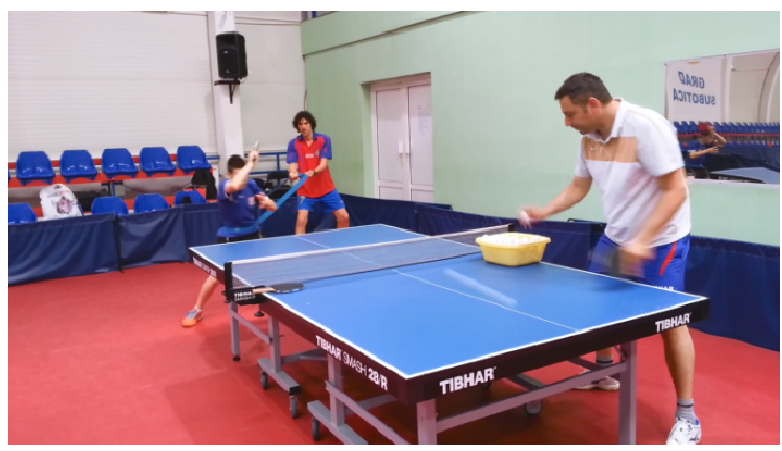

Slika 1: "Many balls" trening 


\section{Zaključak}

Sasvim je sigurno da nije moguće sprovoditi adekvatan trenažni proces u bilo kojoj sportskoj disciplini bez saznanja o nivou razvijenosti fizičkih sposobnosti sportista. Jedini pravi put u uvid stanja funkcionalnih i motoričkih sposobnosti, morfoloških i drugih karakteristika jeste primena standardizovanih dijagnostičkih procedura. Rezultati testova omogućavaju trenerima pravilnu primenu trenažnih operatora $u$ svim segmentima treninga. U radu su prikazane vrednosti maksimalne potrošnje kiseonika $\left(\mathrm{VO}_{2} \mathrm{max}\right)$, kao osnovnog pokazatelja aerobnih sposobnosti dobijene primenom direktne metode određivanja progresivnim kontinuiranim testom na pokretnoj traci, kao i indirektno određivanje VO2 max terenskim Beep testom. Sportskim stručnjacima i igračima od velikog su značaja parametri dobijeni testiranjem funkcionalnih sposobnosti. Osim toga što ukazuju na stanje aerobne sposobnosti testiranih igrača, oni trenerima pomažu u kreiranju trenažnog procesa, odnosno, određivanju obima, intenziteta i metoda primene trenažnih sredstava.

Zbog specifičnosti i karakteristika stonog tenisa najbolje bi bilo primenjivati testove $\mathrm{u}$ kojima se primenjuju kretanja i pokreti udaraca koje stonoteniseri izvode na treningu i meču. Korišćenjem takvih testova u proceni fizičkih sposobnosti stonotenisera, dobila bi se prava slika o specifičnoj kondiciji igrača. 


\section{Literatura}

1. Drid, P. (2012) Teorija sportskog treninga. Novi Sad: Fakultet sporta i fizičkog vaspitanja

2. Đukić, B., Vujkov, N., Kalentić, Ž., Vujanović, S., Ujsasi, D., Sudarov, N., Doder, D. (2014). Intervalni trening u stolnom tenisu. Zagreb: 12. godišnja međunarodna konferencija "Kondicijska priprema sportaša"

3. Fratrić, F. (2006) Teorija i metodika sportskog treninga. Novi Sad: Pokrajinski zavod za sport.

4. Kondrič, M., Hudetz, R., Mandić-Furjan, G. (2010) Osnove stolnoga tenisa. Zagreb: Kineziološki fakultet.

5. Malacko, J., Rađo, I. (2004) Tehnologija sporta i sportskog treninga. Sarajevo: Fakultet sporta i tjelesnog odgoja

6. Suchomel, A. (2010). A Comparison of Exercise Intensity on Different Player Levels in Table Tennis. International Journal of Table Tennis Sciences, No.6, 79-82.

7. Sudarov, N., Fratrić, F. (2010) Dijagnostika treniranosti sportista. Novi Sad: Pokrajinski zavod za sport. 